\title{
RATE OF NATURAL PREDATION OF Anagasta kuehniella EGGS AT DIFFERENT PLANT COMPOSITIONS
}

\author{
VINHA, Fernando Belezini ${ }^{1}$ \\ PASSONI, Eduardo Dias ${ }^{2}$ \\ PINTO, Alexandre De Sene ${ }^{3}$
}

SUMMARY: The parasitoid Trichogramma spp. multiplied in moth eggs Anagasta kuehniella may be released by the technique of spreading the eggs unprotected, but natural predation can be an impediment to this procedure. This study aimed to assess the rhythm of natural predation of A. kuehniella eggs in different vegetation compositions at Moura Lacerda University Center, Ribeirão Preto, Brazil. Three agricultural crops (coffee, sugarcane and pasture), three orchards of fruit trees (mango, lemon and banana) and three thickets were selected. Blue cardboards of 5 x 5 $\mathrm{cm}$ were painted with a thin layer of 50\% gum arabic and then eggs of A. kuehniella were spread evenly over the same. Between 2013, October $14^{\text {th }}$ and $19^{\text {th }}, 10$ cards were distributed in each area mentioned, under the ground, except in orchards, where 5 were fixed in plants and the other 5 placed in the ground, leaving about $1 \mathrm{~m}$ from each other. The cards were placed in the field at 6:00 am and changed every two hours to 18:00 pm. A night evaluation from 18:00 pm to 6:00 am was also performed. There were significant differences among treatments, with a higher average percentage of predation in coffee, sugarcane crop, lemon, banana and thicket areas from landmark and hill of the campus than that in pasture, mango orchard and the lakeside thicket. Predation was more intense from 8:00 to 10:00 am, from 12:00 to 16:00 pm, in general, and in the evening for the most of the vegetables compositions studied.

Keywords: Releasing technique. Biological control. Hymenoptera.

\section{RITMO DE PREDAÇÃO NATURAL DE OVOS DE Anagasta kuehniella EM DIFERENTES COMPOSIÇÕES VEGETAIS}

\begin{abstract}
RESUMO: O parasitoide Trichogramma spp., multiplicado em ovos da traça Anagasta kuehniella, pode ser liberado por avião pela técnica de espalhamento dos ovos sem proteção, mas a predação natural pode ser impeditiva para esse procedimento. Este trabalho teve por objetivos avaliar o ritmo de predação natural de ovos de A. kuehniella em diferentes composições vegetais do Centro Universitário Moura Lacerda, Ribeirão Preto, SP. Foram selecionadas três culturas agrícolas (café, cana-de-açúcar e pastagem), três pomares de fruteiras (manga, limão e banana) e três matas. Cartelas de $5 \times 5 \mathrm{~cm}$ de cartolina azul foram pinceladas com uma fina camada de goma arábica $50 \%$ e depois ovos de A. kuehniella foram espalhadas uniformemente sobre as mesmas. Entre 14 e 19 de outubro de 2013, 10 cartelas foram distribuídas em cada área mencionada, sob o solo, exceto nos pomares, onde 5 foram fixadas na planta e 5 colocadas no solo, ficando aproximadamente $1 \mathrm{~m}$ uma da outra. As cartelas foram colocadas às $6 \mathrm{~h} 00$ no campo e trocadas a cada duas horas, até às $18 \mathrm{~h} 00$. Uma avaliação noturna, das $18 \mathrm{~h} 00$ às $6 \mathrm{~h} 00$ foi realizada também. Houve diferenças significativas entre os tratamentos, sendo a porcentagem média de predação maior em cafeeiro, canavial, limoeiro, bananeira e nas matas da divisa do campus e do morro do que em pastagem, pomar de mangueira e na mata à beira do lago. A predação foi mais intensa das $8 \mathrm{~h} 00$ às $10 \mathrm{~h} 00$, das $12 \mathrm{~h} 00$ às $16 \mathrm{~h} 00$, em geral, e à noite, na maioria das composições vegetais estudadas.
\end{abstract}

Palavras-chave: Técnica de liberação. Controle biológico. Hymenoptera.

\footnotetext{
${ }^{1}$ Graduado em Agronomia no CUML, Mestre em Entomologia pela ESALQ-USP.

${ }^{2}$ Centro Universitario Moura Lacerda

${ }^{3}$ Graduado em Agronomia e Mestrado em Entomologia pela UNESP-FCAV, Doutorado em Entomologia pela ESALQ-USP
} 


\section{INTRODUCTION}

The biological control of pests has been used by man for two thousand years and is characterized by a rational practice of handling organisms populations considered pests using their natural enemies. In Brazil, this control tactic gains strength, as the farmer and consumers are becoming more demanding, the phytosanitary barriers imposed by the exporting countries of our food are more rigorous, more and more pests become resistant to insecticides, among other arguments.

Among the natural enemies of pests, the micro-hymenoptera of the genus Trichogramma (Hymenoptera: Trichogrammatidae) are widely cited as important agents of biological control of lepidoptera-pest worldwide, in diverse crops and in forest areas, due to the ease of its creation and their aggressiveness in the parasitism of insect-pest eggs (BOTELHO, 1997; PARRA et al., 1998).

The parasitoid Trichogramma spp. is employed in biological control programs in 49 countries, adding at that time more than 21 million hectares per year treated with inundative releases of this parasitoid (HASSAN, 1993). However, the information contained in the literature varies from 16 to 32 million hectares year-1, divided into 28 crops using 28 species of the genus Trichogramma (SMITH, 1996; HASSAN, 1997; PARRA, ZUCCHI, 2004).

The success of a biological control program can be hampered by the adopted release technique (PINTO; PARRA, 2002). Pinto et al. (2003) verified that the release of T. galloi in cane fields for the control of Diatraea saccharalis is favored when the parasitoid is brought to the field in the form of pupae and left to emerge when compared to the release of adults. However, Pinto (1999) verified that the predation of $D$. saccharalis eggs in the field is very high, reaching $100 \%$ in many areas, which may also affect the release of Trichogramma in the pupal form. For the release of Trichogramma in the pupal form, the author comments that parasitized eggs need to be packaged in capsules for protection against rain and predators.

On the other hand, Mills et al. (2000) found that the release of Trichogramma pupae on the tops of plants is a viable and efficient technique for the control of Cydia pomonella in apple and pear orchards, in the USA. The authors comment that predation is probably minimized because parasitized eggs are distributed over the leaves of the tree canopy, where predation is less. Rajendran and Mohammed (1998) also found a better efficiency of the distribution technique of parasitized eggs on the cane field than conventional techniques, where eggs are trapped and protected.

In the sugarcane crop, Bonini (2013) verified that the predation of A. kuehniella eggs parasitized by $T$. galloi reaches about $90 \%$ after $24 \mathrm{~h}$ of the release, when these are glued in cartons and unprotected.

Although the aforementioned authors comment on the possibility of predation of Trichogramma pupae to be reduced when using the pupae distribution technique, few trials were conducted to test this technique.

The objective of this trial was to evaluate the natural predation rate of A. kuehniella eggs, used to multiply the parasitoid Trichogramma spp., in different plant compositions.

\section{MATERIAL AND METHOD}

The trials were conducted in the campus of the University Center Moura Lacerda, Ribeirão Preto, SP. The sterilized eggs of Anagasta kuehniella used in the trials were assigned by the Bug biological control agents S/A, from Piracicaba, SP. The experimental design was completely randomized.

For the trials, three crops (sugarcane, coffee tree and pasture with brachiaria), three orchards with fruit species (mango trees, lemon trees and banana trees) and three local on forests (hill, lake and border) 
were selected at Moura Lacerda campus. In the laboratory, 5 x $5 \mathrm{~cm}$ cards of blue paperboard were brushed with a thin layer of 50\% gum arabic and then A. kuehniella eggs were evenly spread over them.

In areas with crops, on October 14, 2013, 10 cards were distributed in each area mentioned, being around $1 \mathrm{~m}$ from each other. On this date, the cards were placed in the field at 6:00 p.m. and evaluated for the percentage of predation, being removed at 06:00 on October 15. On the second day, new cards were placed in these same places at 06:00 and observed throughout the day at intervals of 2 hours, ending at 6:00 p.m.

In the orchard areas, also on October 14, 10 cards were distributed in each area mentioned, 5 being fixed in the plant and 5 placed in the ground near the plant, being approximately $1 \mathrm{~m}$ from each other. On this date, the cards were placed in the areas at 6:00 p.m. and evaluated for the percentage of predation, being removed at 6:00 p.m. on October 15. New cards were placed in these same places at 6:00 am on October 15 and observed throughout the day at 2 hour intervals, closing at 6:00 p.m.

In the forest areas, on October 19, 10 cards were distributed in each area mentioned, being around $1 \mathrm{~m}$ from each other. On this date, the cards were placed in the field at 6:00 a.m. and observed throughout the day at intervals of 2 hours, closing at 6:00 p.m., evaluating the percentage of predation. At 6:00 p.m., new cards were placed in the field, replacing the previous ones, being withdrawn at 6:00 p.m. on October 20 .

The data were submitted to the homoscedasticity test, to determine the best form of analysis. From the values obtained, the average percentage of predation accumulated in each evaluation time was calculated. The calculated means were compared by the Tukey test, at the 5\% level.

\section{RESULTS AND DISCUSSION}

In the areas with crops, the average percentage of predation was higher in the coffee tree at all times of evaluation, differing significantly from the pasture area with brachiaria. The sugar cane area had statistically higher predation than the pasture area at almost all times, except from 6:00 a.m. to 8:00 a.m. and from 12 a.m. to 2:00 p.m. (Figure 1). At the end of the daytime period, predation was significantly higher in the area of coffee tree (96.1\%) and sugarcane (87.8\%) than in the brachiaria area $(60.0 \%)$.

In coffee tree and sugarcane, the average percentage of accumulated predation exceeded $80 \%$ between 12.00 and 14.00 (Figure 1). The greatest predation occurred from 8:00 a.m. to 10:00 a.m. and from 12 a.m. to 2:00 p.m. in all crops.

At night, predation was statistically higher in the area with sugarcane (98.0\%), differing only from that observed in brachiaria (65.2\%) (Figure 2).

In the orchard trial, the average percentage of predation during the day was higher in the lemon tree area, on ground, at all times of evaluation, differing significantly from all treatments, except in the banana area, on ground, in all periods, except also from 10:00 a.m. to 12:00 p.m., where it differed from all (Figure 3). 
Figure 1. Average accumulated percentage of predation of Anagasta kuehniella eggs in unprotected soil samples from three different crops at the campus of Moura Lacerda, Ribeirão Preto, SP, 2013. Points followed by the same letters do not differ by Tukey test ( $\mathrm{p}<0.05)$.

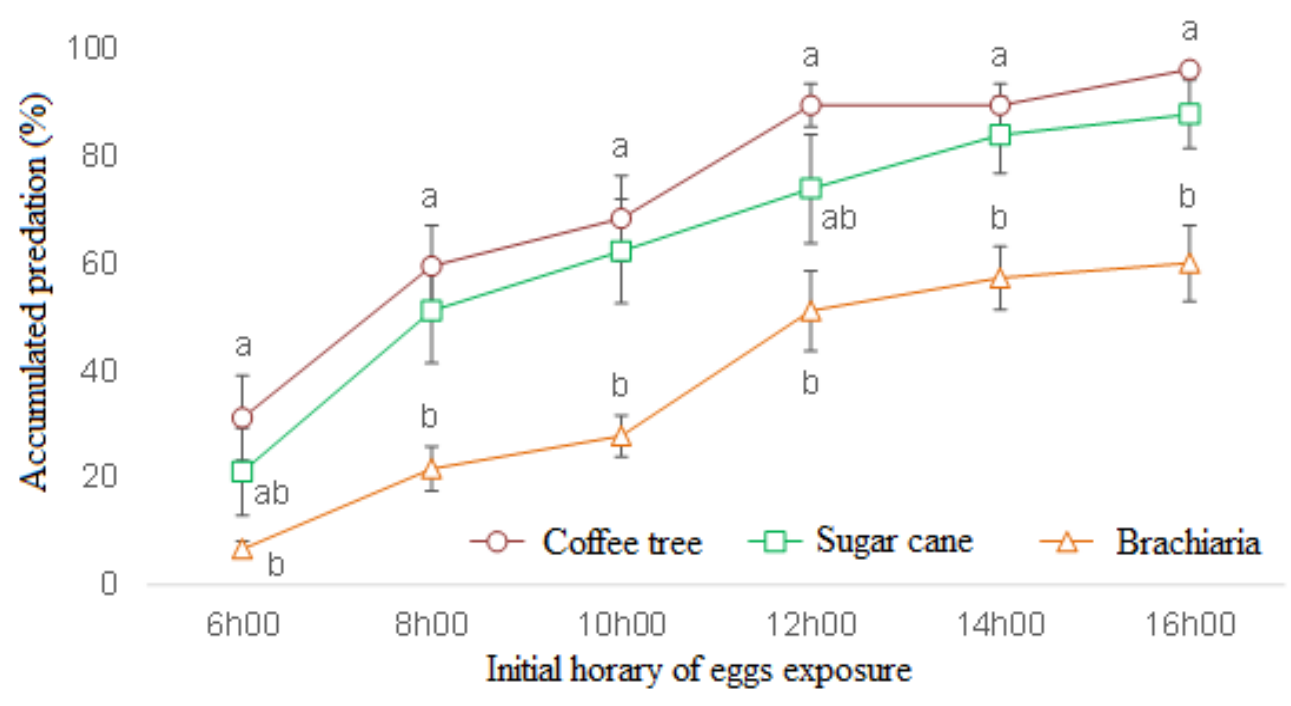

Figure 2. Average percentage of nocturnal predation of Anagasta kuehniella eggs in unprotected soil samples from three different crops at the campus of Moura Lacerda, Ribeirão Preto, SP, 2013. Points followed by the same letters do not differ by Tukey test $(\mathrm{p}<0.05)$.

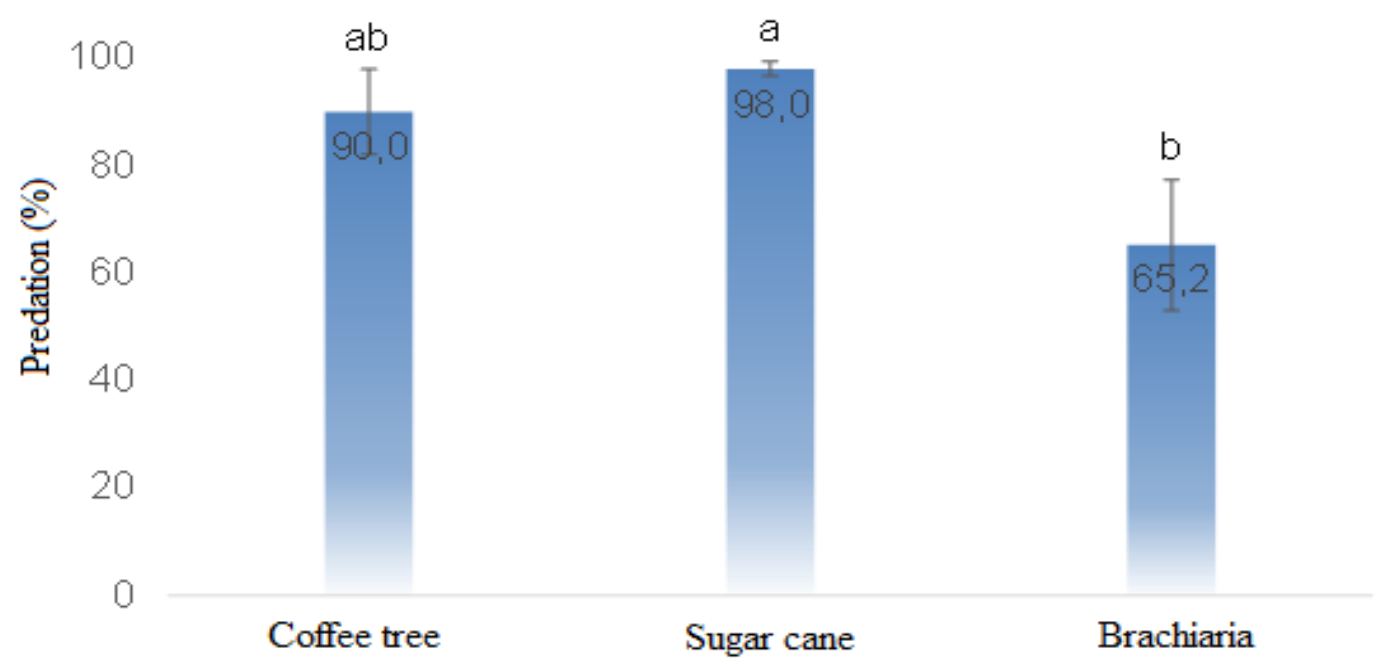

Treatments where egg cartons were placed on the leaves of the plants did not differ in any evaluation period. Predation on ground of the mango area was the lowest in almost all evaluated periods, except from $14 \mathrm{~h} 00$ to $18 \mathrm{~h} 00$, where predation on banana plants was lower. Even with the mango tree orchard ground with the lowest average predation percentage, there were no significant differences with the values obtained in plants of all orchards (Figure 3). The highest average percentage of predation occurred from 8:00 a.m. to 10:00 a.m. and from 2:00 p.m. to 4:00 p.m. in general. 
Figure 3. Average cumulative percentage of predation of Anagasta kuehniella eggs in unprotected ground cards and plants of three distinct orchards at the campus of Moura Lacerda, Ribeirão Preto, SP, 2013. Points followed by the same letters do not differ by Tukey test $(\mathrm{p}<0.05)$.

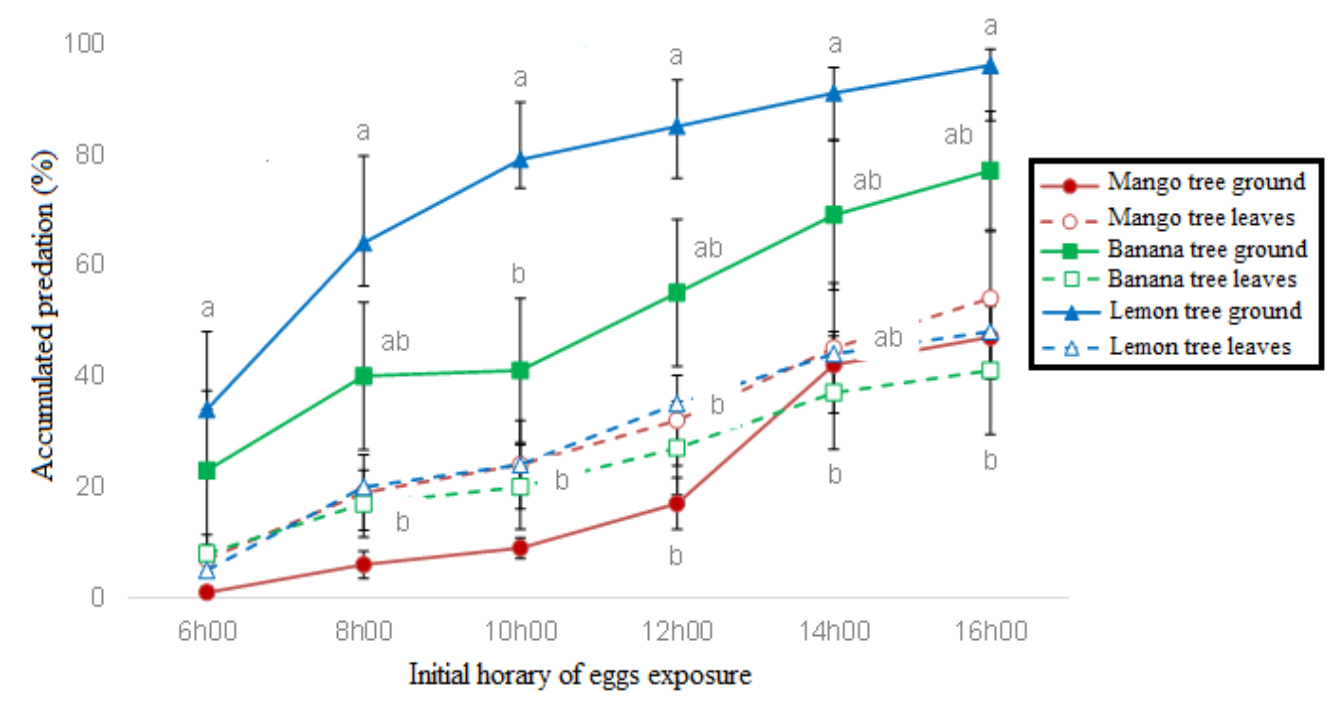

At night, predation was statistically higher in lemon tree crops (90\% ground and $100 \%$ leaves) and banana orchard ground (87\%), differing from the ground treatment of the mango trees area (69\%), which did not differ from the banana leaves treatment (46\%) and differed from the treatment of mango tree leaves (Figure 4).

Figure 4. Average percentage of nocturnal predation of Anagasta kuehniella eggs in unprotected groundcard stands and plants of three distinct orchards at the campus of Moura Lacerda, Ribeirão Preto, SP, 2013. Points followed by the same letters do not differ by Tukey test $(\mathrm{p}<0.05)$.
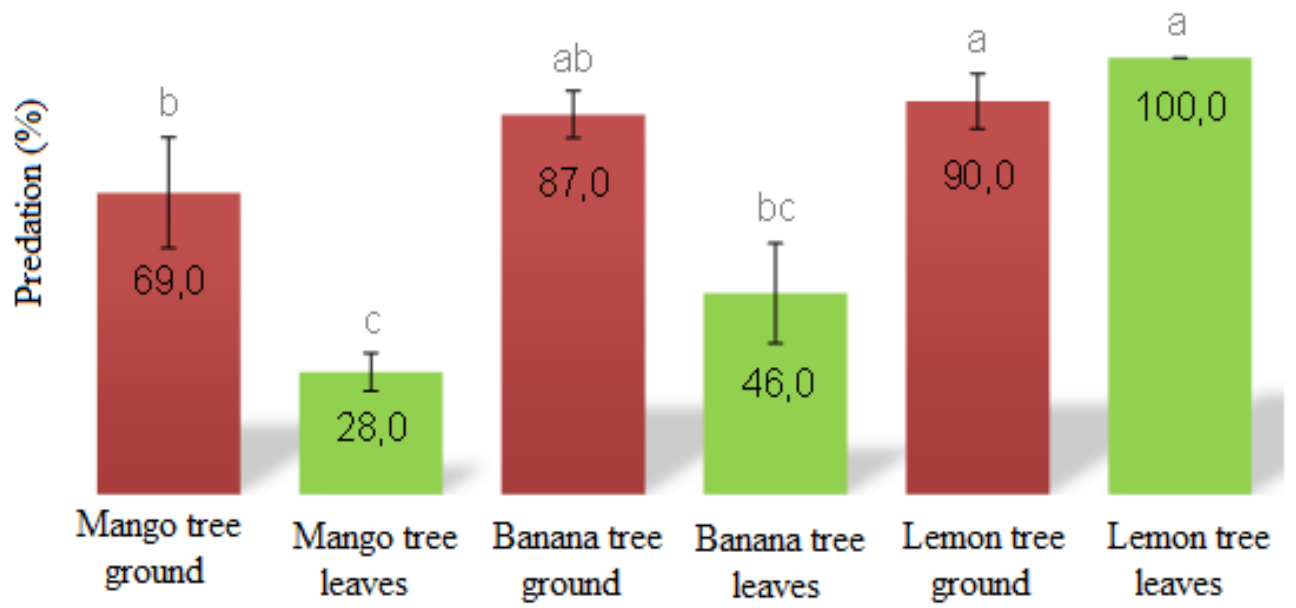

In the forest areas, the average percentage of daytime predation was higher in the forest border at the campus, reaching $100 \%$ at noon and differing from other treatments that did not differ statistically (Figure 6). In the forest border, the highest predation occurred between 8.00 and 12.00, while in the others it was between 10.00 and 12.00 (Figure 5). The greatest predation occurred from 12.00 to 14.00 in all the forests. At night, predation was statistically higher in the forest of the border (100\%), differing from the forest hill (71\%) and the lake (29\%), which also differed from each other (Figure 6). 
Figure 5. Average cumulative percentage of predation of Anagasta kuehniella eggs in unprotected cartons under the soil of three distinct forests at the campus of Moura Lacerda,Ribeirão Preto, SP, 2013. Points followed by the same letters do not differ by Tukey test $(\mathrm{p}<0.05)$.

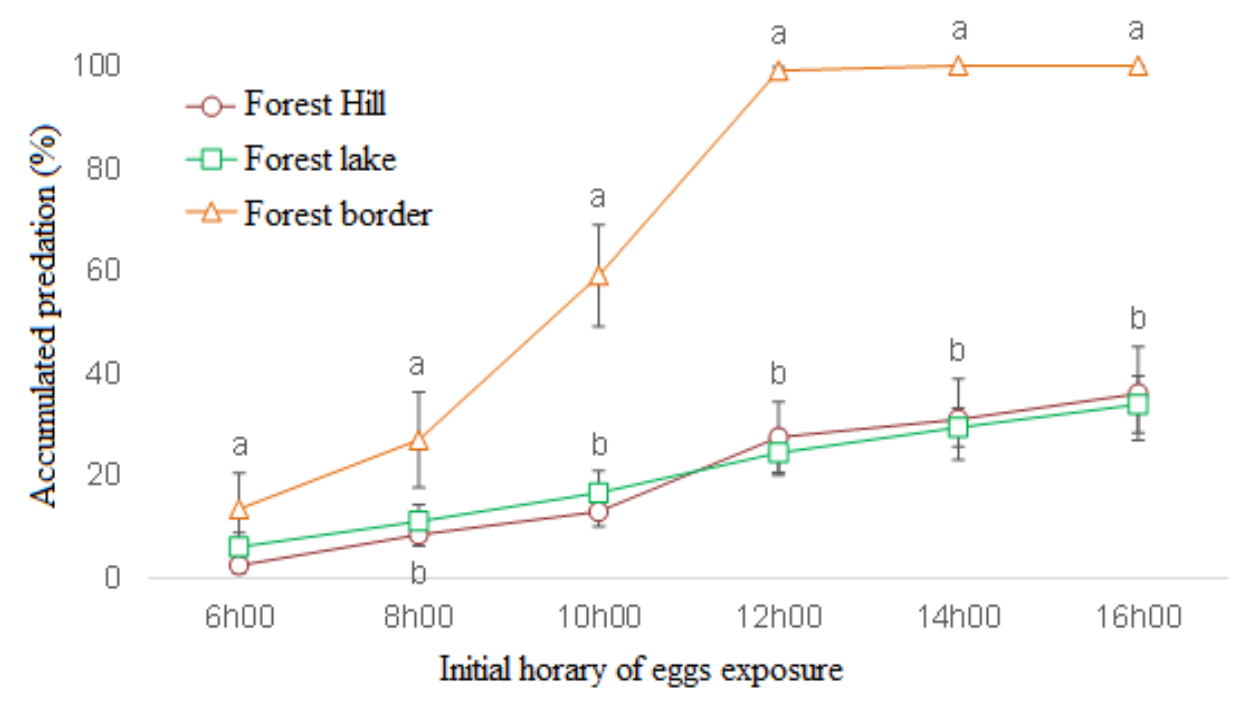

Figure 6. Average percentage of nocturnal predation of Anagasta kuehniella eggs in unprotected cartons under the soil of three distinct forests at the campus Moura Lacerda,Ribeirão Preto, SP, 2013. Points followed by the same letters do not differ by Tukey test ( $\mathrm{p}<0.05)$.

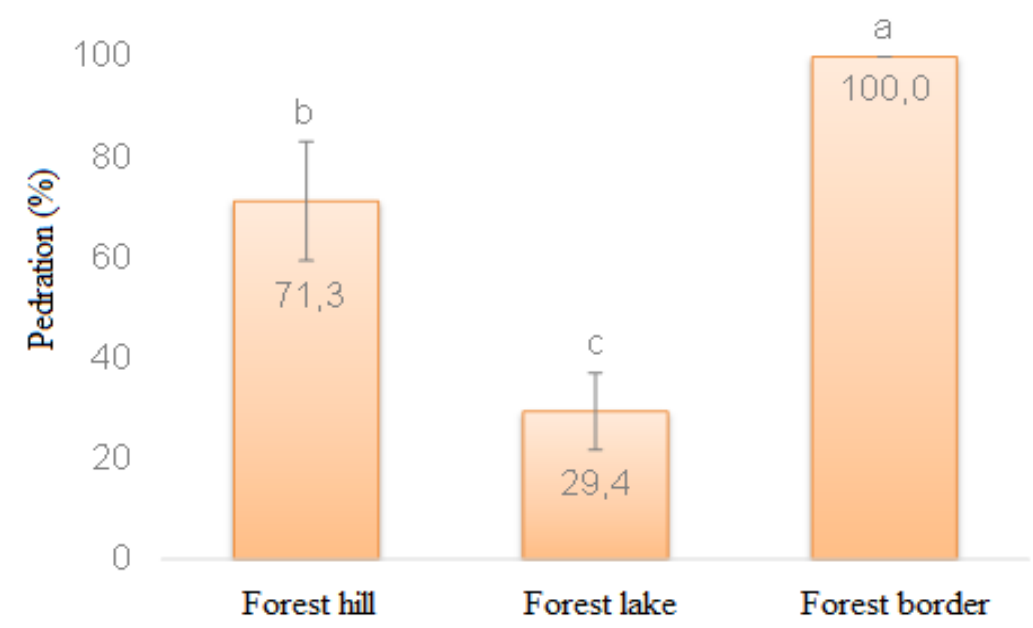

The predation observed at $24 \mathrm{~h}$ in all the current trial areas was superior to that of Pereira et al. (2004), which reached about $90 \%$ only after 7 days of exposure, in an olive orchard.

Martins (2010) observed the predation of $100 \%$ of Anagasta kuehniella eggs parasitized by Trichogramma pretiosum not protected under canevial soil, after $24 \mathrm{~h}$ of exposure, not the same with protected eggs (capsules). Bonini (2013) also observed large predation (90\%) of A. kuehniella eggs parasitized or not by $T$. pretiosum on sugarcane soil. The results obtained in the current trial agree with the two previous authors.

For the release of Trichogramma, it is only possible to use cards with unprotected A. kuehniella eggs in capsules or something similar if the adults are near the emergency, if the quantity released is increased and if these cards are placed under the plants, the predation in soil makes this technique unfeasible. Martins (2010) verified less predation of unprotected parasitoids when they were distributed under the leaves of the plants, being the same discussed by Mills et al. (2000). Even so, release under 
plants would be very costly and would probably also make this practice unfeasible. Of course, new trials should be conducted in different regions to evaluate predation in several agroecosystems, trying to identify and quantify predatory species, especially ants, in these sites. With the collection of more data, a general rule can be defined for the release of A. kuehniella eggs parasitized by Trichogramma spp. without protective capsules.

\section{CONCLUSIONS}

The average percentage of Anagasta kuehniella eggs predation is higher in the ground than in the leaves of the plants. The predation in areas of coffee tree, sugarcane, lemon tree and banana tree is higher than in pasture areas with brachiaria and mango trees. In addiction, The predation is greater in the forest borders and hill than in the edge of the forest lake.

\section{REFERENCES}

BONINI, C.F. Predação de pupas de Trichogramma pretiosum após liberação em canavial. 2013. $29 f$. Monografia (Conclusão do Curso de Agronomia) - Centro Universitário Moura Lacerda, Ribeirão Preto.

BOTELHO, P.S.M. Eficiência de Trichogramma em campo. In: PARRA, J.R.P; ZUCCHI, R.A. (eds.). Trichogramma e o controle biologico aplicado. Piracicaba: Fealq, 1997. p.303-318.

HAJI, F.N.D. et al. Tecnologia de produção massal de Trichogramma spp. Petrolina: Embrapa CPATSA, 1998. 24p.

HASSAN, S.A. The mass rearing and utilization of Trichogramma to control lepidopterous pests: achievements and outlook. Pesticide Science, v.37, p.387-391, 1993.

HASSAN, S.A. Seleção de espécies de Trichogramma para uso em programas de controle biológico. In: PARRA, J.R.P.; ZUCCHI, R.A. (eds.) Trichogramma e o controle biologico aplicado. Piracicaba: Fealq, 1997. p.183-205.

MARTINS, J.F. de O. Predação de pupas de Trichogramma pretiosum em diferentes técnicas de liberação e eficiência da técnica de espalhamento de pupas no controle de ovos de lepidópteros no campo. 2010. 37f. Monografia (Conclusão do Curso de Agronomia) - Centro Universitário Moura Lacerda, Ribeirão Preto.

MILLS, N. et al. Mass releases of Trichogramma wasps can reduce damage from codling moth.

California Agriculture, v.54, n.6, p.22-25, 2000.

PARRA, J.R.P. Técnicas de criação de Anagasta huehniella, hospedeiro alternativo para produção de Trchograma. In: PARRA, J.R.P.; ZUCCHI, R.A (eds.). Trichogramma e o controle biológico aplicado. Piracicaba: Fealq, 1997. p.121-150.

PARRA, J.R.P.; ZUCCHI, R.A. Trichogramma in Brazil: feasibility of use after twenty years of research. Neotropical Entomology, v.33, n.3, p.271-281, 2004.

PEREIRA, J.A. et al. Ants as predators of the egg parasitoid Trichogramma cacoeciae (Hymenoptera: Trichogrammatidae) applied for biological control of the olive moth, Prays oleae (Lepidoptera:

Plutellidae) in Portugal. Biocontrol Science and Technology, v.14, n.7, p.653-664, 2004. 
PINTO, A. de S. Comparação de técnicas de liberação e atuação de Trichogramma galloi zucchi, 1988 em infestações artificiais de Diatraea saccharalis (fabr., 1794) prejudiciais à cana-de-açúcar 1999.

83f. Tese (Doutorado em Entomologia) - Escola Superior de Agricultura “Luiz de Queiroz", Universidade de São Paulo, Piracicaba.

PINTO, A. de S.; PARRA, J.R.P. Liberação de inimigos naturais, cap.19. In: PARRA; J.R.P.; BOTELHO, P.S.M.; CORREAA-FERREIRA, B.S.; BENTO, J.M.S. (orgs.). Controle biológico no Brasil: parasitóides e predadores. São Paulo: Manole, 2002. p.325-342.

PINTO, A. de S.; PARRA, J.R.P.; OLIVEIRA, H.N. de; ARRIGONI, E. De B. Comparação de técnicas de liberação de Trichogramma galloi Zucchi (Hymenoptera: Trichogrammatidae) para o controle de Diatraea saccharalis (Fabricius) (Lepidoptera: Crambidae). Neotropical Entomology, v.32, n.2, p.311318, 2003.

RAJENDRAN, B.; MOHAMMED, H.A. Efficacy of different techniques for the release of Trichogramma chilonis Ishii, parasitising sugarcane internode borer, Chilo sacchariphagus (Kapur). Journal of Entomological Research, v.22, n.4, p., 1998. 